\title{
SISTEM INFORMASI INDEKS UNTUK REKAM MEDIS
}

\author{
Desi Budiarti $^{1}$, Jerhi Wahyu Fernanda ${ }^{2}$, Meida Cahyo Untoro ${ }^{3}$ \\ ${ }^{1,2,3}$ Institut IImu Kesehatan Bhakti Wiyata Kediri \\ desi.budiarti.db@gmail.com ${ }^{1,2,3}$
}

\begin{abstract}
Information technology is currently a very important need for the people included in the health field. In hospitals, information technology is used in managing medical records. Most of the medical records in Indonesia managing medical records manually. This study aims to provide a overview of a model medical record information system that is able to produce disease index, operation index, doctor index and patient index. This application is web based application that made by using PHP programming language and MySQL as its database. In manufacturing, this application is customized to the needs of medical records in general by conducting interviews with medical records clerk. This Application can make disease index, procedure index, doctor index and patient index. Besides indexes for medical records, this application can also generate reports 10 major diseases and procedures both inpatient and outpatient.
\end{abstract}

Keywords: Information Systems, Medical Record, Index

\begin{abstract}
Abstrak
Teknologi informasi saat ini menjadi kebutuhan yang sangat penting bagi masyarakat termasuk dalam bidang kesehatan. Di Rumah sakit, teknologi informasi dimanfaatkan dalam mengelola rekam medis. Sebagian besar unit rekam medis di Indonesia mengelola rekam medis secara manual. Penelitian ini bertujuan untuk memberikan gambaran sebuah model sistem informasi rekam medis yang mampu menghasilkan indeks penyakit, tindakan, dokter dan pasien. Aplikasi ini dibuat berbasiskan web dengan menggunakan bahasa pemrograman PHP dan MySQL sebagai basis datanya. Dalam pembuatannya, aplikasi ini disesuaikan dengan kebutuhan rekam medis pada umumnya dengan melakukan wawancara terhadap petugas rekam medis. Hasil dari aplikasi ini dapat membuat indeks penyakit, indeks tindakan, indeks dokter dan indeks pasien secara otomatis. Selain indeks-indeks untuk rekam medis, aplikasi ini juga dapat menghasilkan laporan 10 besar penyakit dan tindakan baik rawat inap maupun rawat jalan.
\end{abstract}

Kata kunci: Sistem Informasi, Rekam Medis, Indeks

\section{PENDAHULUAN}

Perkembangan teknologi informasi saat ini berkembang sangat pesat. Saat ini informasi menjadi kebutuhan yang sangat penting bagi masyarakat. Perkembangan dan pemanfaatan teknologi komputer juga sudah ada di berbagai bidang, yaitu di bidang perdagangan, bidang pertanian, bidang industri, bidang pendidikan, dan bidang lainnya termasuk juga dalam bidang Kesehatan.

Rumah sakit sebagai salah satu institusi pelayanan kesehatan membutuhkan keberadaan suatu sistem informasi yang akurat dan andal, serta cukup memadai untuk meningkatkan pelayanannya kepada para pasien serta lingkungan yang terkait lainnya.

Pengelolaan data di rumah sakit merupakan salah satu komponen yang penting dalam mewujudkan suatu sistem informasi di rumah sakit. Pengelolaan data dimaksudkan untuk menghasilkan laporan-laporan internal dan eksternal rumah sakit. Pengelolaan data secara manual, mempunyai banyak kelemahan, selain membutuhkan waktu yang lama, keakuratannya juga kurang dapat diterima, karena kemungkinan kesalahan sangat besar (Handoyo, 2008). 
Seiring dengan kemajuan teknologi informasi dan kesehatan serta tuntutan akan kebutuhan data yang cepat dan tepat, rumah sakit saat ini terus mengembangkan dan memanfaatkan rekam medis untuk menjadi alat yang dapat merekam dan menampilkan data secara cepat dan tepat (Hatta, 2010). Sistem Informasi rekam medis merupakan sebuah sistem yang mencakup hampir seluruh kegiatan di rumah sakit. Keterangan mengenai pasien secara lengkap meliputi identitas pribadi, sosial, dan semua keterangan lain menyangkut pasien terdapat dalam rekam medis (Markus, 2010). Namun dari sistem informasi rekam medis tersebut, masih terdapat beberapa kelemahan, salah satunya adalah tidak tercakupnya pelaksanaan indeksing yaitu membuat tabulasi sesuai kode yang sudah dibuat ke dalam indeks-indeks, yang berguna memberikan referensi kepada pengguna. Indeksing masih dilakukan secara semi-computerize yaitu memasukkan manual kedalam aplikasi pengolah data seperti Ms. Word atau Ms. Excel, hal ini pula yang terjadi pada Rumah Sakit X di Kediri. Rumah Sakit X menggunakan Sistem Informasi Rumah Sakit berbasis desktop dimulai dari pendaftaran hingga pelaksanaan kodefikasi penyakit namun belum mencakup pelaksanaan indeksing.

Berdasarkan permasalahan tersebut, penulis tertarik untuk membuat sistem yang dapat menghasilkan indeks-indeks yang terintegrasi dengan sistem informasi rumah sakit sehingga mudah diakses oleh berbagai pihak yang membutuhkan seperti tenaga medis atau pihak perencanaan rumah sakit dll.

Adapula tujuan dari penelitian ini, yaitu Menghasilkan aplikasi sistem informasi berbasis web dinamis yang mampu mengolah data-data masukan menjadi indeks-indeks yang dibutuhkan didalam Unit Rekam Medis dan diharapkan dapat bermanfaat dalam pengembangan Rekam Medis Elektronik.

\section{METODE}

Desain penelitian yang digunakan adalah Survei deskriptif dengan teknik sampling Simple Random Sampling. Sampel penelitian ini adalah petugas rekam medis sebagai informan yang memberikan informasi agar sistem yang akan dibuat sesuai dengan kebutuhan di lapangan.

\section{Diagram Konteks Sistem}

Diagram konteks adalah diagram yang memberikan gambaran umum terhadap kegiatan yang berlangsung dalam sistem.

Entitas luar yang terlibat langsung dalam sistem ini adalah Admin, Pendaftaran dan Rekam Medis. Berikut merupakan pembagian privilages untuk masing-masing entitas:

a Admin memiliki hak akses tertinggi sehingga ia dapat mengontrol semua pengguna yang ada dibawahnya yaitu Pendaftaran dan Rekam Medis. Admin ini biasanya digunakan untuk seorang yang melakukan pemeliharaan (maintenance) sistem.

b Pendaftaran memiliki akses untuk menambah dan mengubah informasi pasien serta melakukan perubahan (update) pelayanan pasien.

c Rekam Medis memiliki akses untuk pengolahan rekam medis seperti assembling, Koding dan mencetak Indeks. Selain itu petugas juga dapat memanajemen data Penyakit dan Tindakan.

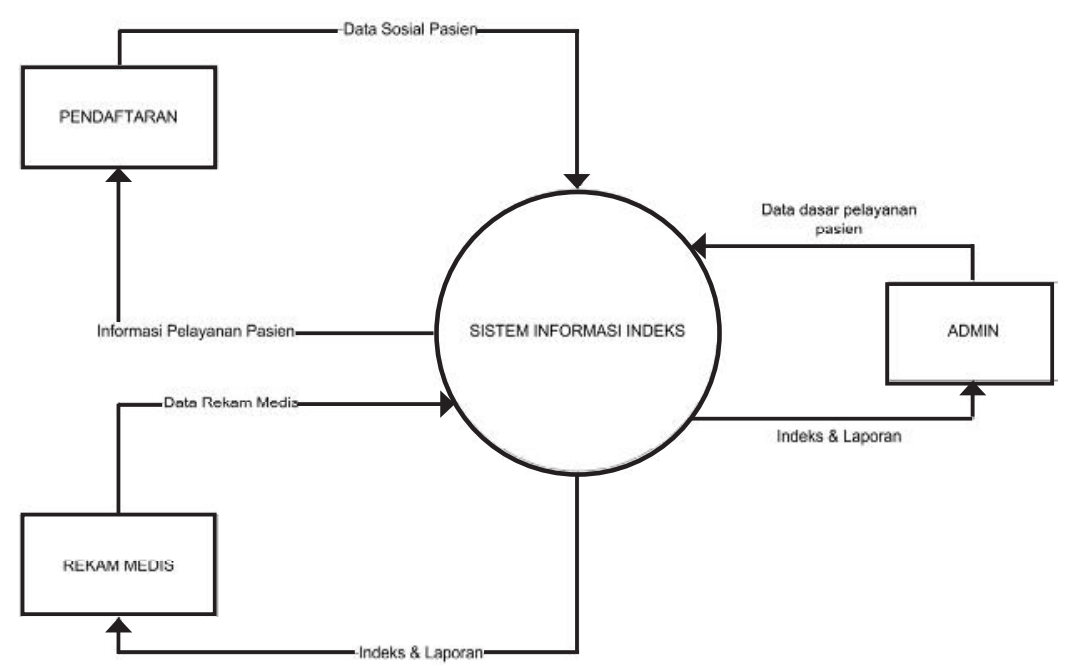

Gambar 1. Diagram Konteks Sistem 
Jurnal Manajemen Informasi Kesehatan Indonesia Vol. 3 No.2 Oktober 2015 ISSN: 2337-6007 (online); 2337-585X (Printed)

\section{DFD Level 1 Sistem}

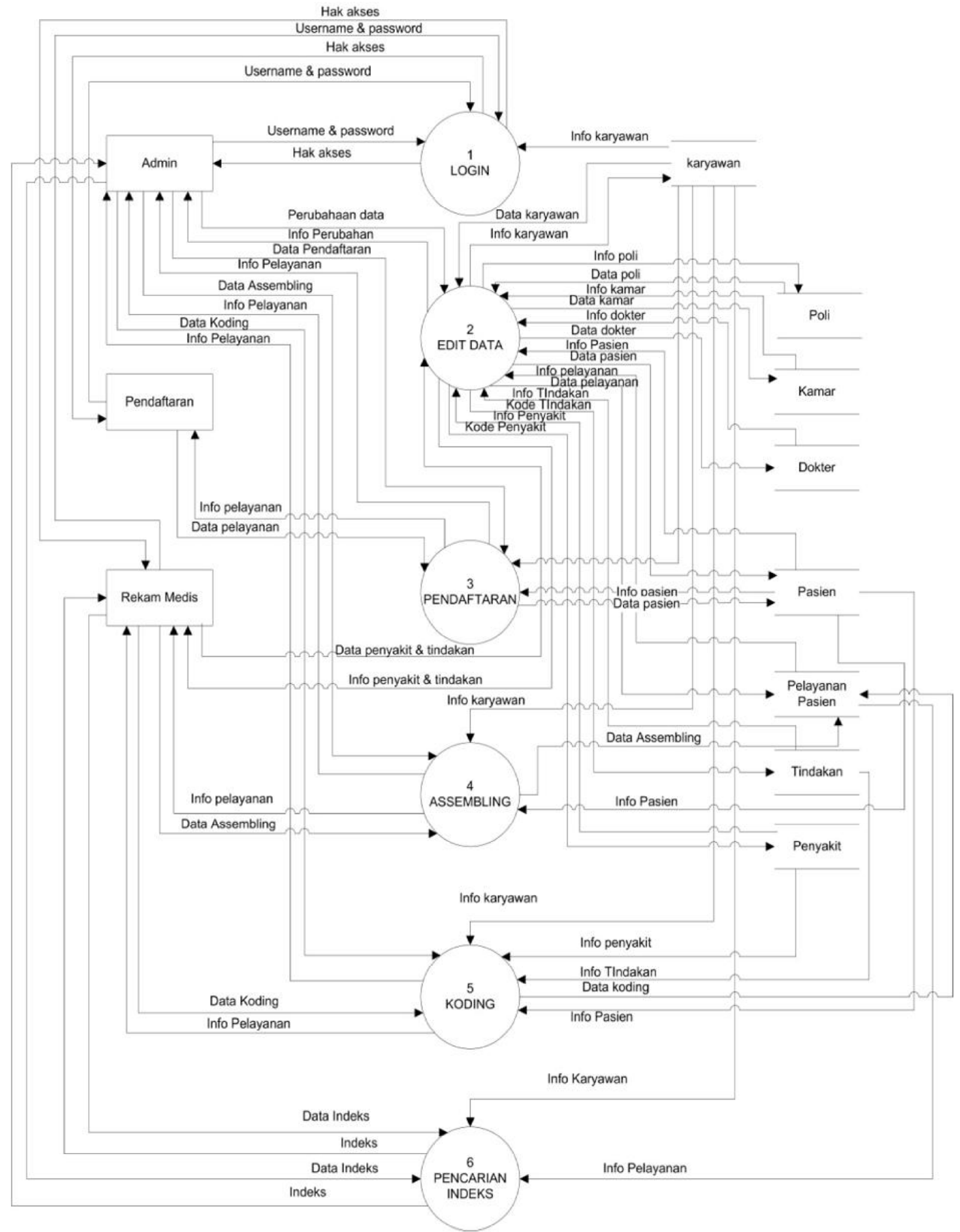

Gambar 2. DFD Level 1 Sistem 


\section{DFD Level 2 Sistem}

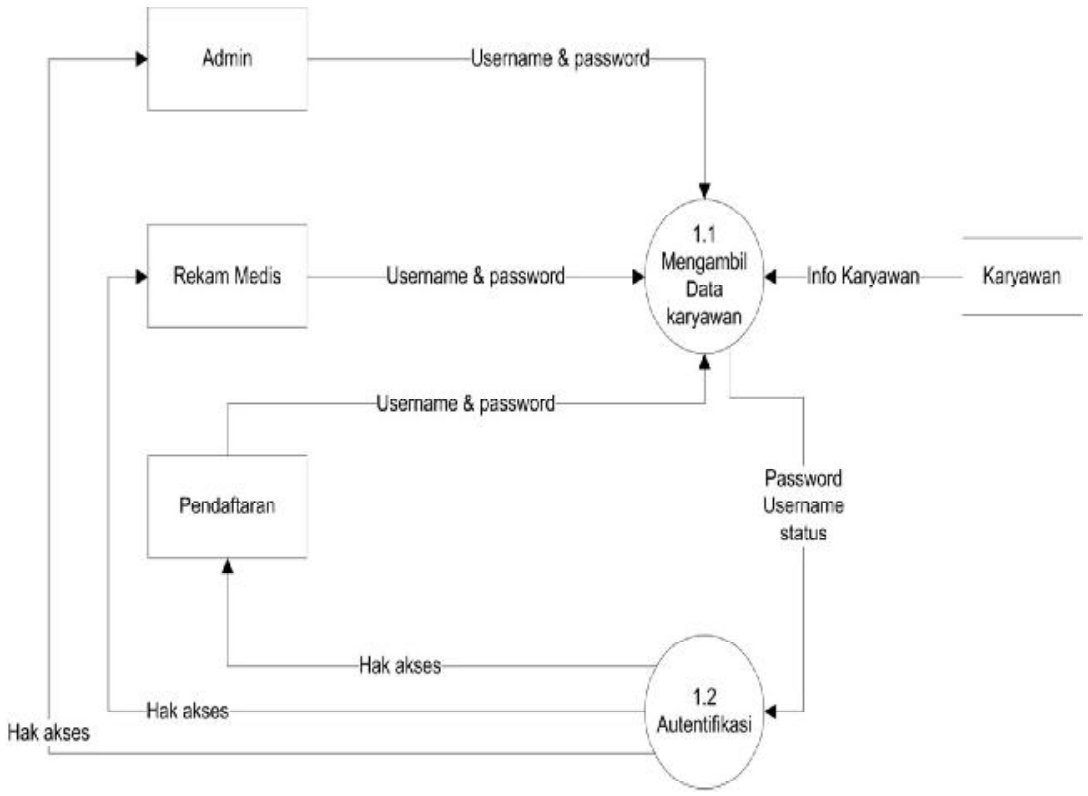

Gambar 3. DFD Level 2 Proses Login

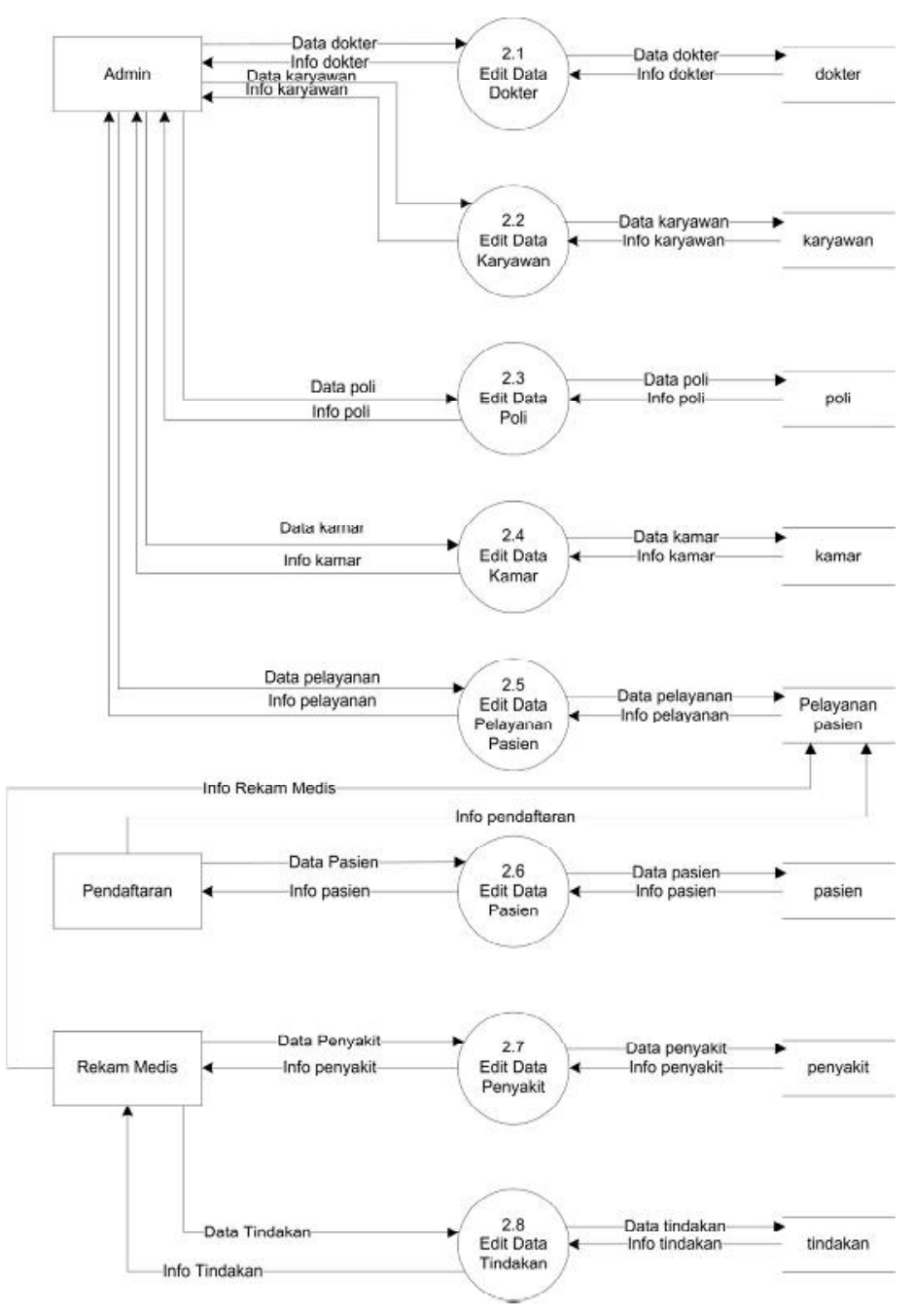

Gambar 4 DFD Level 2 Proses Edit Data 
Jurnal Manajemen Informasi Kesehatan Indonesia Vol. 3 No.2 Oktober 2015 ISSN: 2337-6007 (online); 2337-585X (Printed)

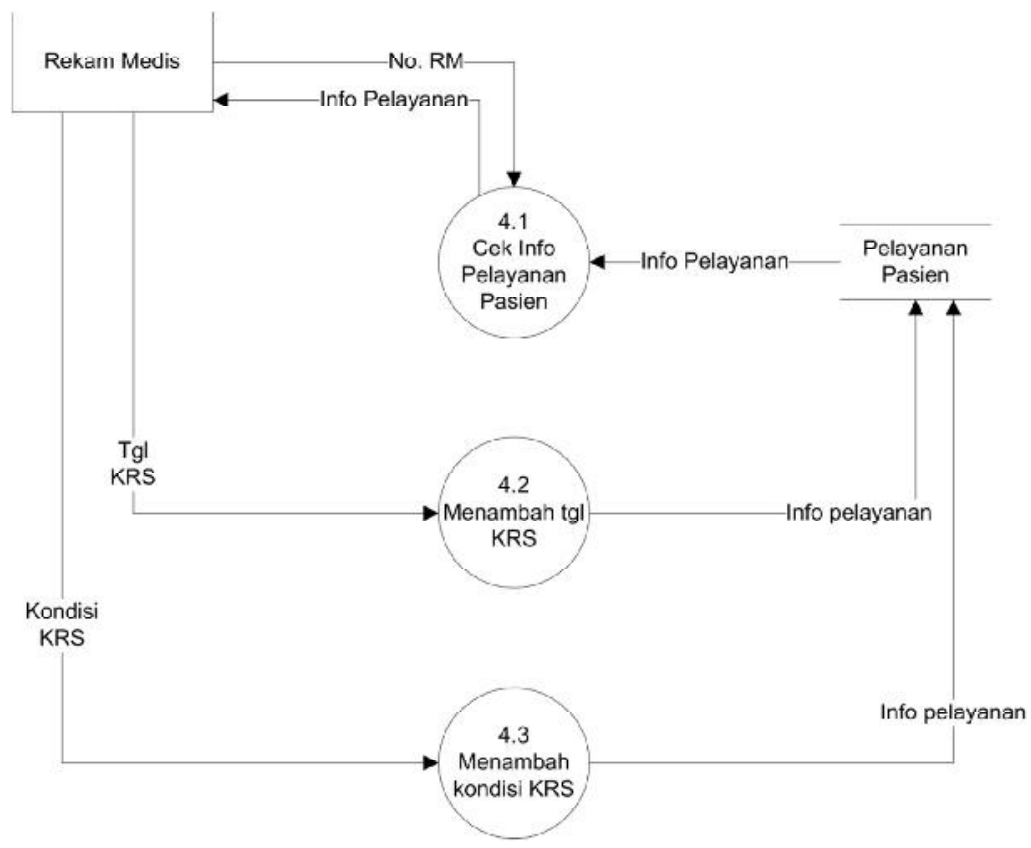

Gambar 5. DFD Level 2 Proses Pendaftaran

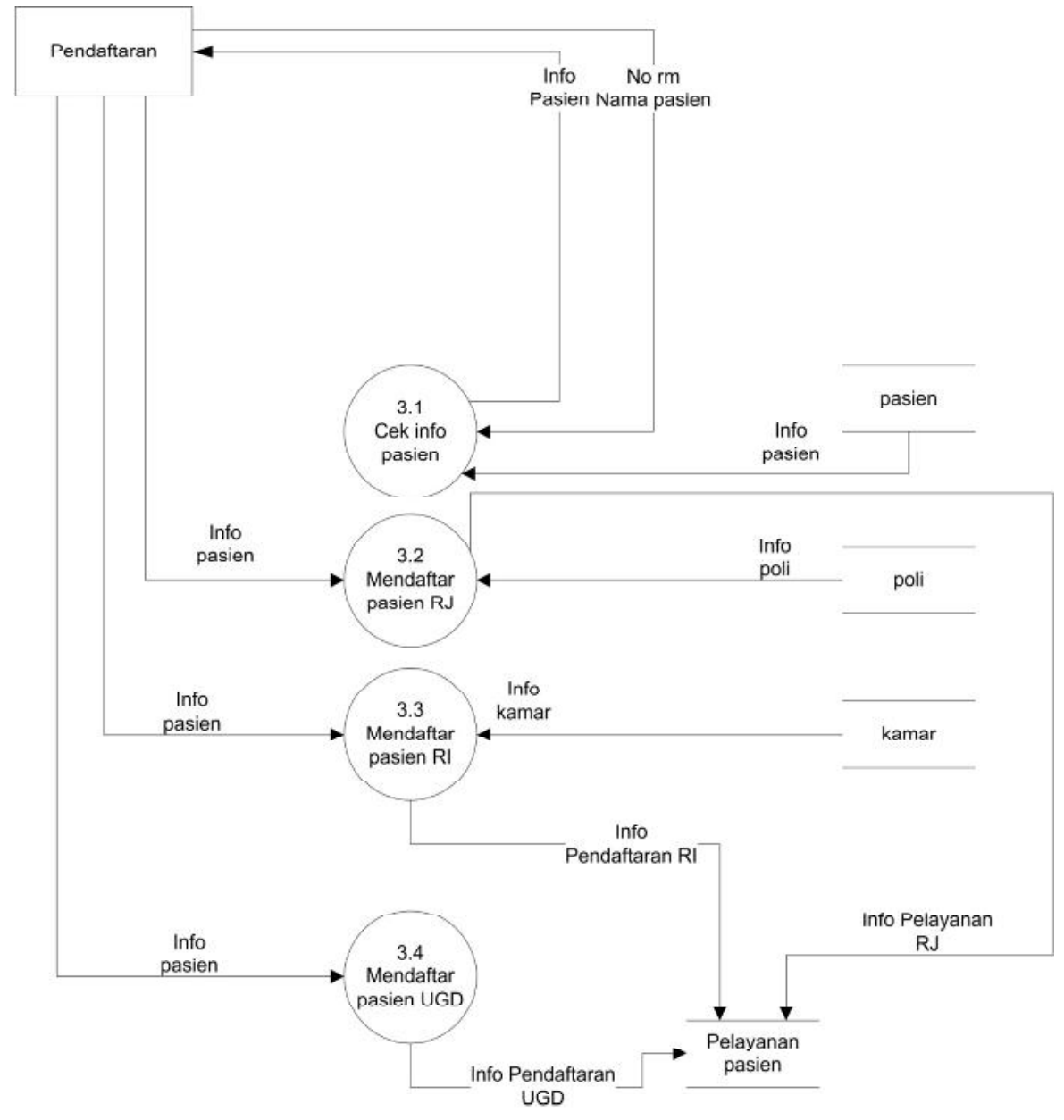

Gambar 6. DFD Level 2 Proses Assembling 
Desi Budiarti, dkk. Sistem Informasi Indeks untuk Rekam Medis

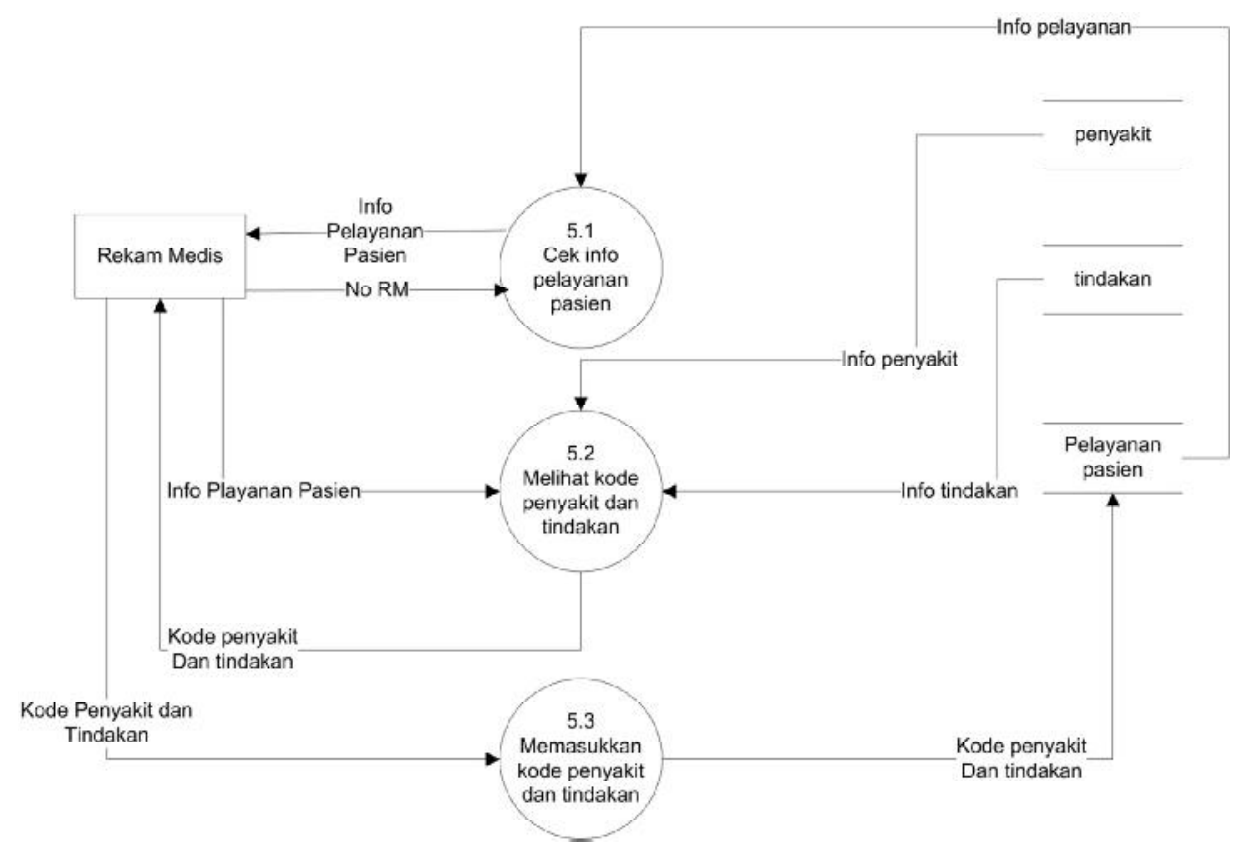

Gambar 7. DFD Level 2 Proses Koding

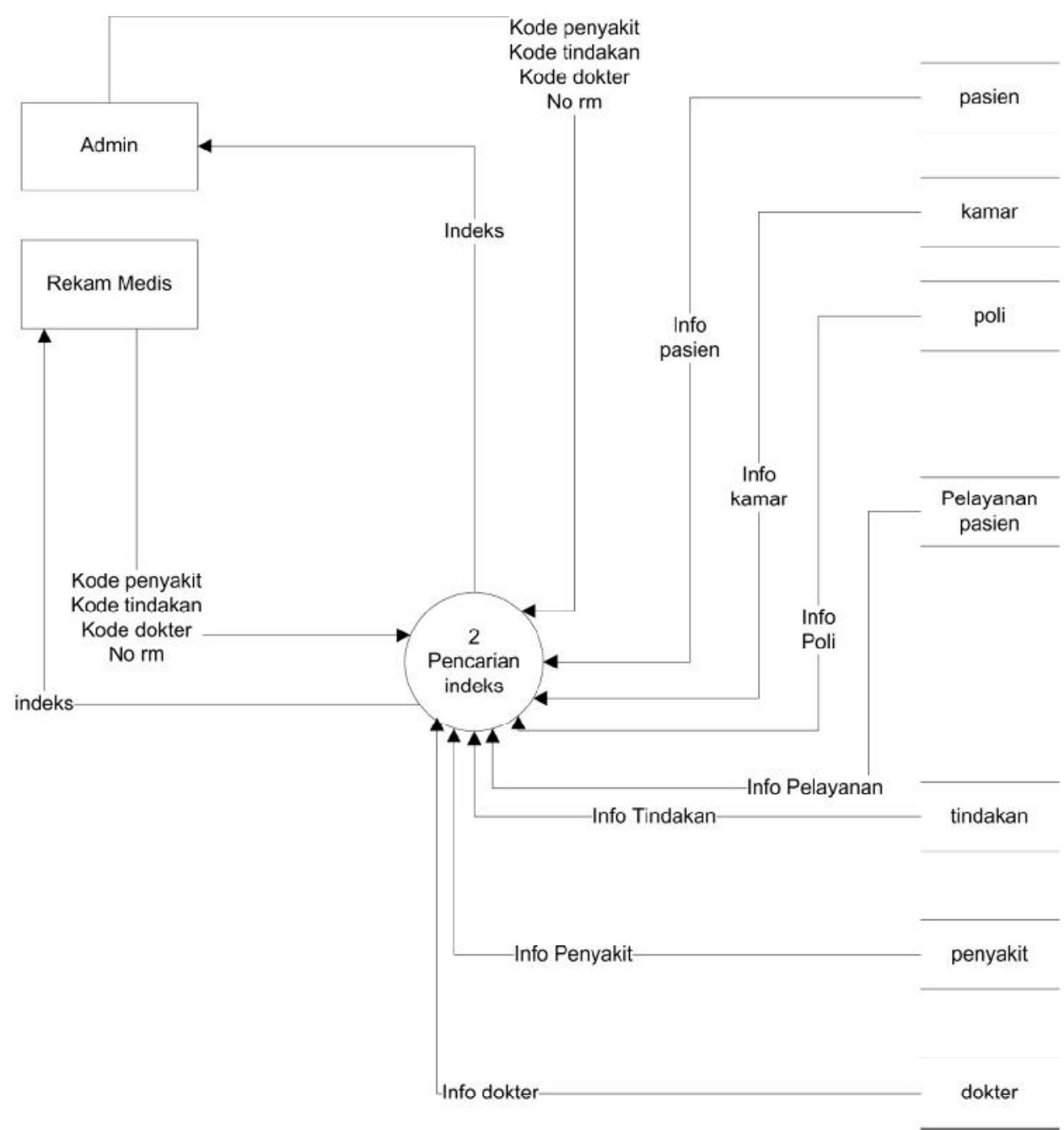

Gambar 8. DFD Level 2 Proses Pencarian Indeks 


\section{HASIL}

\section{HASIL}

\section{Sistem Penamaan}

Menggunakan sistem penamaan langsung sesuai dengan tanda pengenal pasien.

\section{Sistem Penomoran}

Menggunakan sistem penomoron Unit Numbering System, yaitu memberikan satu nomor rekam medis baik kepada pasien baru maupun pasien lama. Sehingga berkas rekam medis disimpan dalam satu folder dengan nomor rekam medis yang sama.

\section{Sistem Penyimpanan dan penjajaran.}

Menggunakan sistem penyimpanan sentralisasi dan sistem penjajaran Terminal Digit Filing

\section{Sistem Pendaftaran}

Kegiatan pendaftaran di Rumah Sakit X sudah menggunakan aplikasi berbasis visual basic. Petugas hanya perlu mencari data pasien didalam database jika itu pasien lama, namun jika pasien adalah pasien baru, petugas akan melakukan identifikasi pasien terlebih dahulu dan meng-input-kan data tersebut kedalam database.

\section{Assembling Rekam Medis}

Setiap berkas rekam medis yang telah selesai dipergunakan di Ruang inap akan di Assembling dan dianalisa kelengkapannya. Untuk berkas yang belum lengkap akan dikembalikan ke ruang inap untuk dilengkapi maksimal 14 hari. Setelah dilengkapi, petugas Assembling akan menyerahkan dokumen ke bagian kodefikasi untuk di kode dan dikembalikan ke filing. Bagian assembling akan menghasilkan laporan analisa kelengkapan setiap 3 bulan sekali dan akan dilaporkan ke Komite Medis untuk peningkatan kualitas dan kuantitas rekam medis.

\section{Kodefikasi Penyakit}

Pelaksanaan kodefikasi penyakit yang dicakup oleh Sistem Informasi Rumah Sakit X hanyalah kodefikasi rawat jalan, Sementara kodefikasi rawat inap hanya dikode di dokumen rekam medis tanpa memasukkan ke dalam database Sistem Informasi Rumah Sakit.

\section{Indeksing}

Instalasi rekam medis menyediakan indeks pasien, dokter, penyakit, operasi/ tindakan dan kematian. Indeks pasien, sudah dilakukan secara elektronik dan tersimpan pada database rumah sakit. Sementara indeks lainnya masih dilakukan secara manual menggunakan Ms. Excel.

Petugas koding akan merangkap membuat indeks dengan cara memasukkan data pasien ke dalam form di Ms.Excel. Form tersebut berisi nomor rekam medis, umur, jenis kelamin, diagnosa, tindakan, lama dirawat, dokter, jenis pasien, kamar, lama dirawat.

Dari data yang dimasukkan kedalam form tersebut, akan menghasilkan laporan 10 besar penyakit dan tindakan yang dilaporkan setiap bulan kepada Direktur dan Komite Medik.

\section{PEMBAHASAN}

Dari hasil penelitian dan perancangan, Sistem Informasi Indeks ini memiliki 3 level atau status pengguna yaitu pendaftaran, rekam medis dan administrator. Status pendaftaran hanya dapat mengakses menu Home, Pendaftaran dan Edit Data Pasien saja, untuk status rekam medis dapat mengakses menu Home, Assembling, Koding dan Indeks sementara Administrator dapat mengakses keseluruhan sistem tersebut.

\section{Tampilan Sistem}

Tampilan halaman login akan muncul saat aplikasi pertama kali dibuka. Pengguna harus memasukkan username dan password. Sistem akan masuk ke menu selanjutnya sesuai status yang telah terdata di database aplikasi.

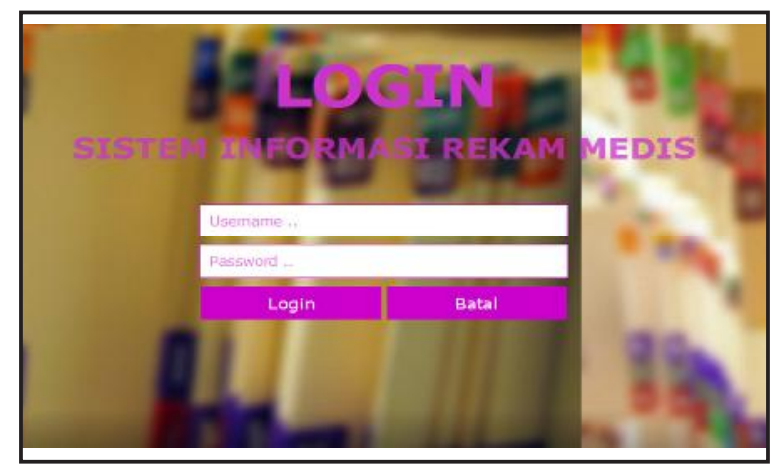

Gambar 9. Halaman Login 


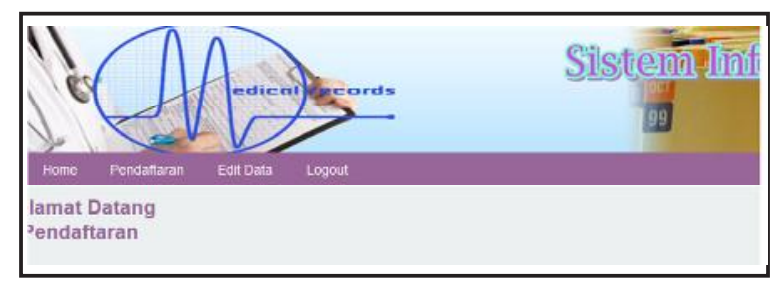

Gambar 10. Halaman Hak Akses Pendaftaran

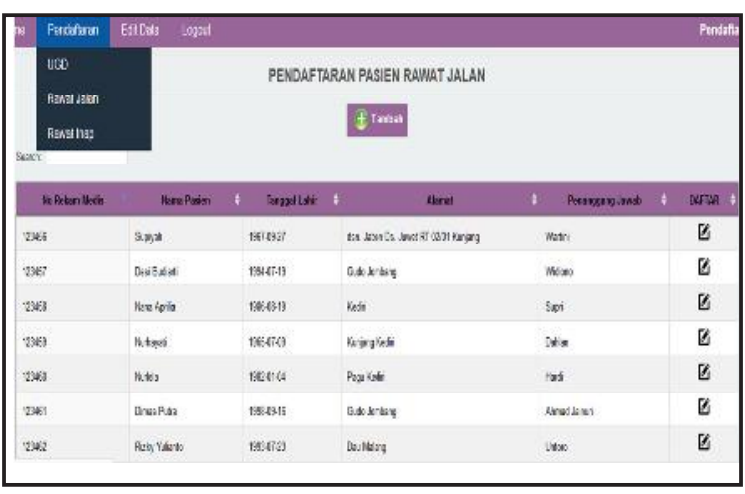

Gambar 11. Menu Pendaftaran

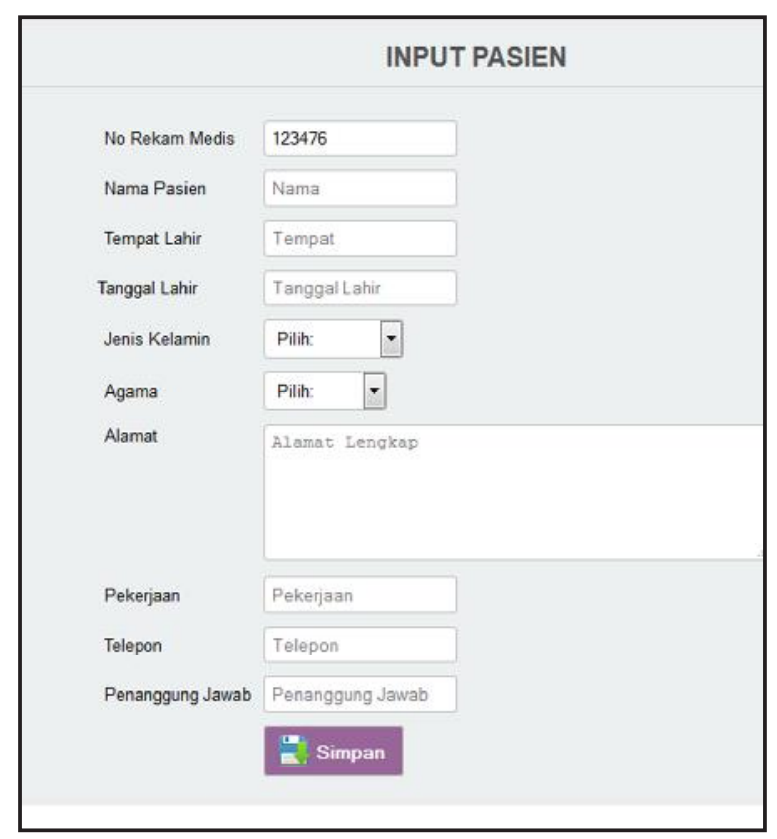

Gambar 12. Menambahkan Pasien Baru

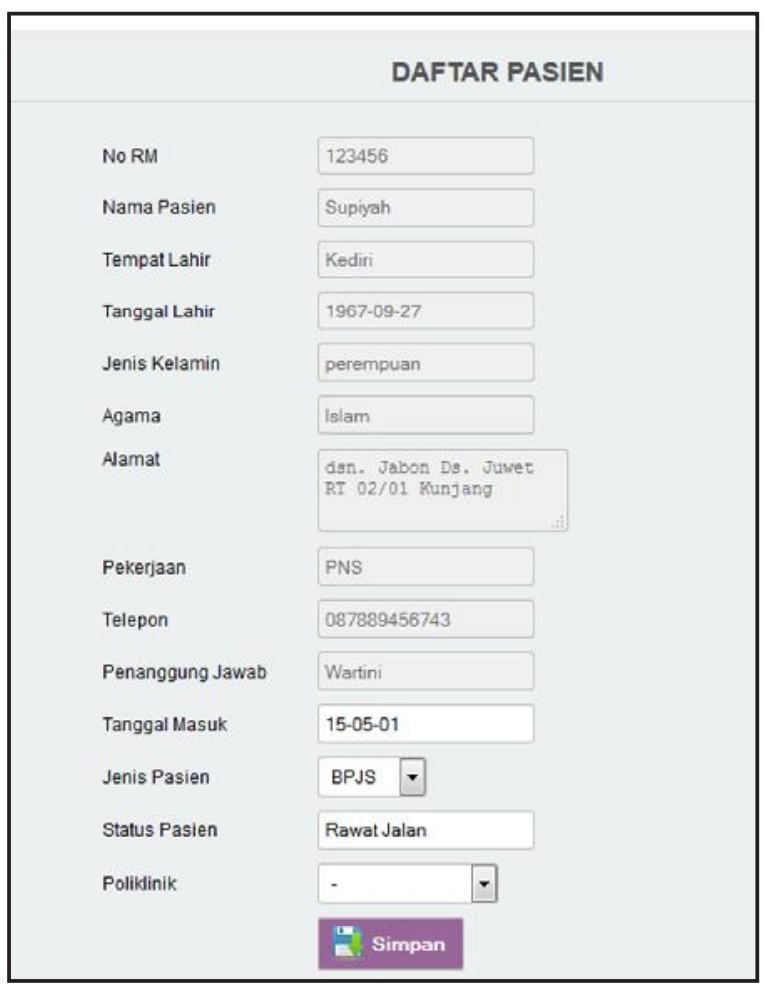

Gambar 13. Mendaftarakan Pelayanan Pasien

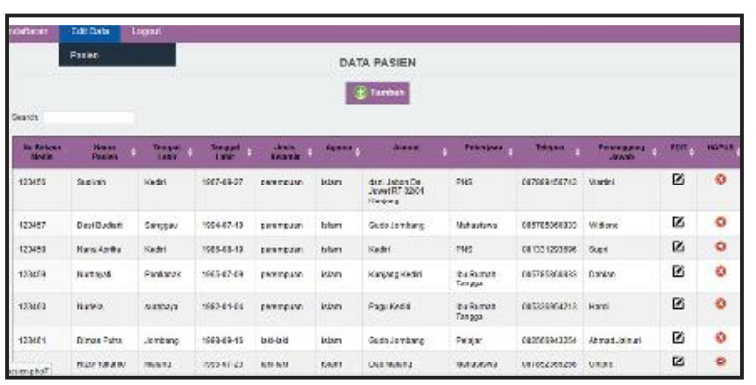

Gambar 14. Menu Edit Data Pasien

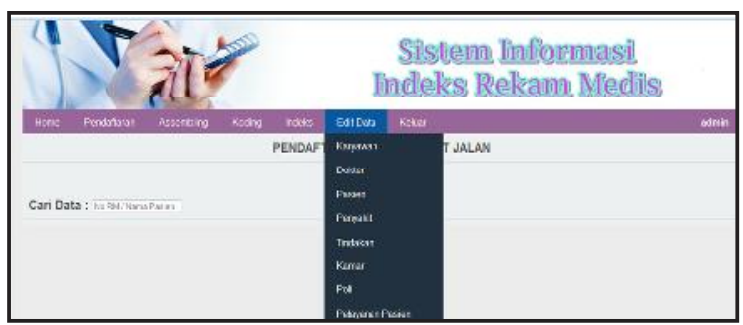

Gambar 15. Halaman Hak Akses Rekam Medis 


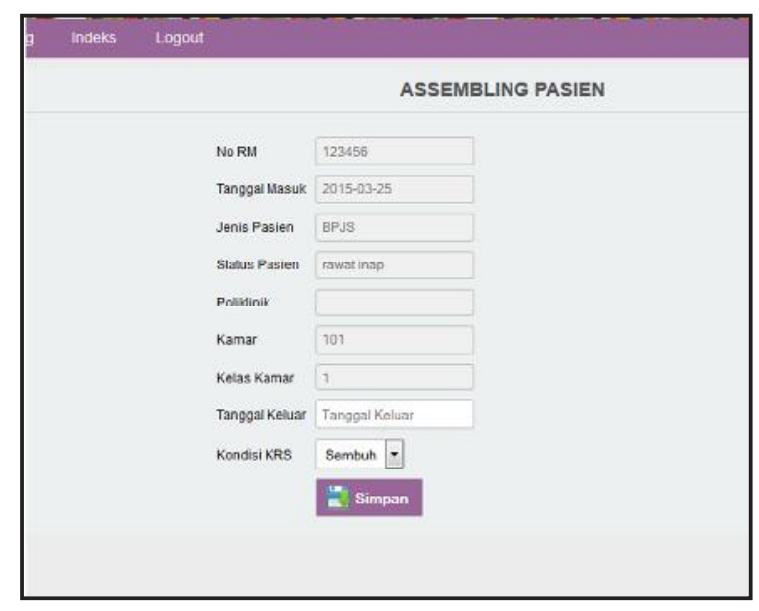

Gambar 16. Halaman Assembling

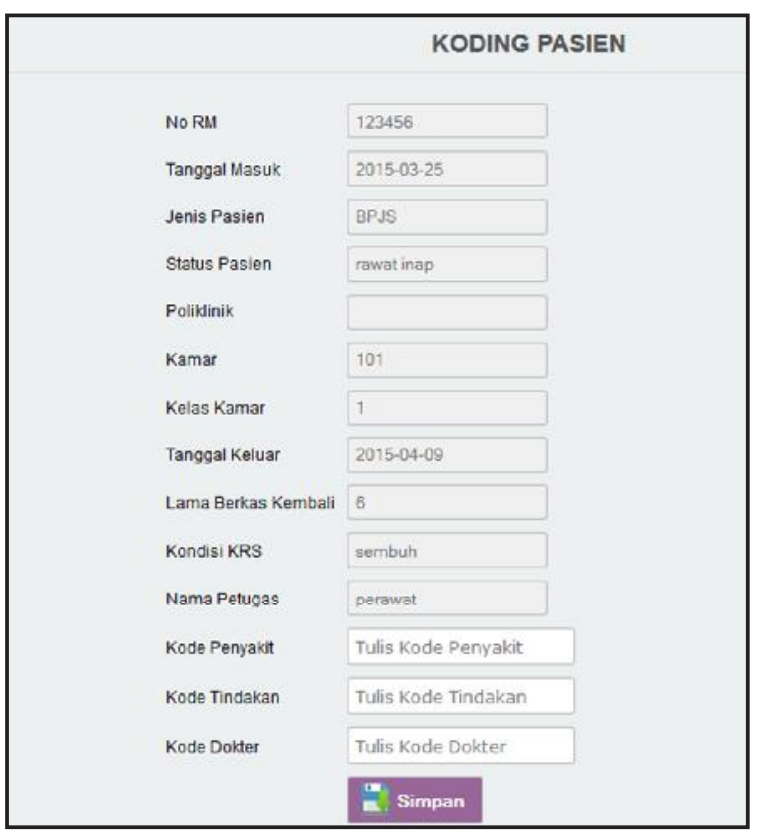

Gambar 17. Halaman Koding

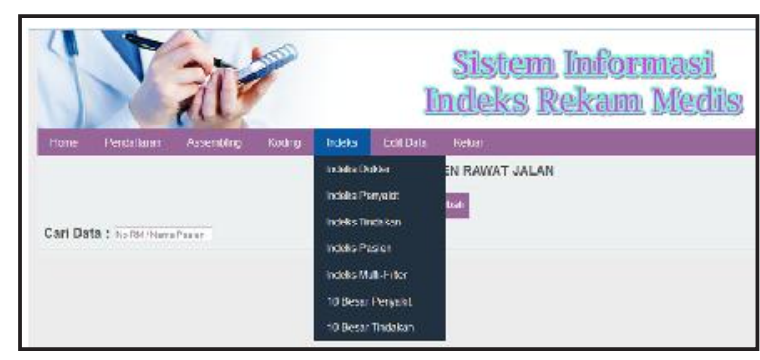

Gambar 18. Menu Indeks

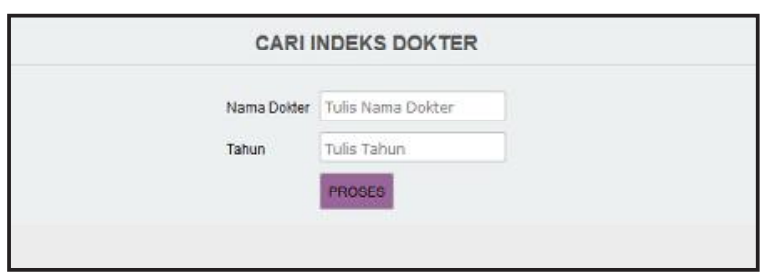

Gambar 19. Pencarian Indeks Dokter

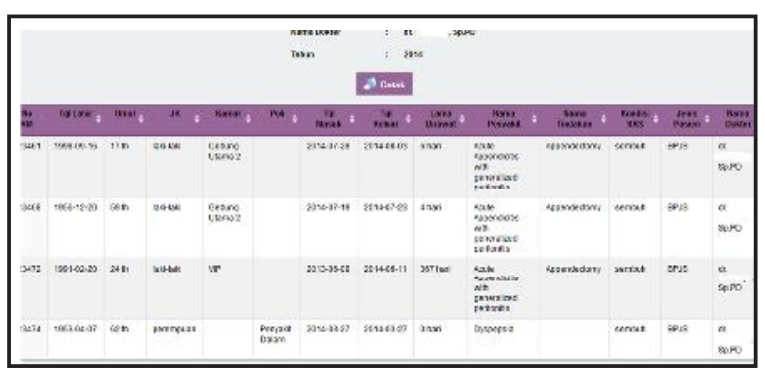

Gambar 20. Hasil Pencarian Indeks Dokter

\section{SIMPULAN}

Dari penelitian pembuatan Sistem Informasi Indeks Untuk Rekam Medis di Rumah Sakit ini dapat diambil beberapa kesimpulan, antara lain:

1. Sistem Informasi Indeks ini dapat mendukung pelaksanaan kegiatan rekam medis pada umumnya, dimulai dari kegiatan Pendaftaran, Assembling, Koding dan Indeksing.

2. Sistem Informasi Indeks ini dapat menghasilkan 4 indeks yang dibutuhkan oleh Unit Rekam Medis yaitu Indeks Pasien, Indeks Penyakit, Indeks Tindakan dan Indeks Dokter dalam periode 1 tahun.

3. Sistem Informasi Indeks ini dapat menghasilkan Laporan 10 besar penyakit dan tindakan baik rawat inap maupun rawat jalan dalam periode 1 tahun.

\section{DAFTAR PUSTAKA}

Andi. 2012. Adobe Dreamweaver CS6 dan PHPMySQL untuk pemula. Yogyakarta : Andi OFFSET.

Handoyo, E. 2008. Aplikasi Sistem Informasi. Aplikasi Sistem Informasi Rumah Sakit Berbasis Web Pada Sub-Sistem Farmasi Menggunakan Framework Prado, 7(1), 13. 
Hatta, G. R. 2010. Pedoman Manajemen Informasi Kesehatan di Sarana Pelayanan Kesehatan. Jakarta: Penerbit Universitas Indonesia.

Kadir, Abdul. 2014. Pengenalan Sistem Informasi Edisi Revisi. Yogyakarta: Andi OFFSET.

Markus, S. N. 2010. Master Plan Pengembangan Sistem Informasi Manajemen Rumah Sakit. Yogyakarta : Poltekes Permata Indonesia.

Notoatmodjo,S. 2012. Metode Penelitian Kesehatan. Jakarta: Rineka Cipta.

Paillin, D. B. 2012. Perancangan Sistem Informasi Penjualan Pada Toko Ribo Jaya Ambon. 6(1), 69-70.

Peraturan Menteri Kesehatan Republik Indonesia no. 269 tahun 2008 tentang Rekam Medis.
Depkes RI. 1997. Pedoman Pengelolaan Rekam Medis Rumah Sakit di Indonesia. Revisi I. Jakarta : Dirjend Yanmed.

Rustiyanto, E. 2014. Buku Ajar Sistem Informasi Manajemen Rumah Sakit. Yogyakarta : PI Press.

Solichin, A. 2010. http://achmatim.net/2010/01/30/ buku-gratis-mysql-5-dari-pemula-hinggamahir/. [Diakses tanggal 28 Nopember 2014. Pukul 04.41 WIB].

Tohari, H. 2014. Astah Analisa Serta Perancangan Sistem Informasi Melalui Pendekatan UML. Yogyakarta : Andi OFFSET.

Undang Undang Republik Indonesia no. 44 Tahun 2009 Tentang Rumah Sakit. 